\title{
慢性関節リウマチ長期観察例の病態
}

$\begin{array}{cccc}\text { 九州大学医学部整形外科 } & & \\ \text { 塚 } & \text { 本 行 } \\ \text { 有 } & \text { 富 } & & \text { 寛 }\end{array}$

\section{Follow Up Assessment of Rheumatoid Arthritis}

By

\section{Y. Tsukamoto \& H. Aritomi}

Department of Orthopaedic Surgery, Faculty of Medicine, Kyushu University.

Thirty-five patients with classical rheumatoid arthritis have been followed for more than five years. The average duration of disease of the series was 13.5 years and the average age was 50.0 years.

The series was collected between 1960 and 1964.

In 1966 and 1971, the follow up assessments were carried out on laboratory finding, disease activity, functional capacity and $\mathrm{X}$-ray findings.

On the whole their level of disease activity tended to subside. However, there was a gradual but progressive worsening in the functional capacity. With regard to X-ray findings, the development of the radiological changes varied with the joints involved.

Intercarpal joints and radio-carpal joints were most frequently involved and the $\mathrm{X}$-ray changes of those jojnts progressed rapidly.

In spite of beeing frequently affected, the $X$-ray changes of knee joints and ankle joints were less advanced in comparison with intercarpal joints and radio-carpal joints.

\section{I. 緒 \\ 言}

昭和 41 年度 および本年度リウマチ学会総会の 2 回 にわたり，昭和 35 年より昭和 39 年までに九大整形外 科を受診した慢性関節リウマチ患者を対象とし，ての 疾患の経過を知る目的で行なったアンケート調查の結 果を報告した.

その際， 41 年度 調查時に平均䍜病年数 8.5 年であ った患者群は，5年経過後の現在では全身活動性およ び関節局所の活動性ともにやや鎮静化汇向う症例が増 加しているのに対し，ADL は時の経過とと屯に障害 度を増す傾向にあるととを知った。

しかしてれらの調查結果は患者自身による評価であ るため，それが実態と一致するあのであるかどうかは 疑問が残される. そのため, これらのアンケート調查 症例のうち現在に至るまで長期間持続的に管理し続け た 27 症例を中心とし，断続的ではあるが 5 年以上に
わたって比較可能な調査資料をむつ 8 症例を加えて, それらの長期観察例の病態について経時的な変動の検 討を試みた。

\section{II. 調 查 対 象}

調查対象は緒言で述べたように 5 年以上にわたって 比較可能な調查資料をもつ Classical Rheumatoid Arthritis 35 例であり, その内訳は男性 6 例, 女性 29 例である.

平均罹病年数は 13.5 年, 平均年令は 50.0 才であ る.

\section{III. 検查所見の变動}

1. Latex slide test (RA-Test)

昭和 40 年度の RA-Test 陽性例は 35 例 中 30 例で あり，その陽性率は $85.7 \%$ 亿達する。，一方，昭和 46 年の調查時には 40 年度の陽性 30 例中 12 例が陰性で 
あり， 40 年度陰性であった 5 例中 2 例が陽性に転じ， したがってその陽性率は 35 例中 20 例, $57.1 \%$ であ る.

昭和 40 年度と 46 年度のごく限られた断面での比較 ではあるが， 5 年の経過は RA-Test 陰性例の增加を あたらしている.

慢性関節リウマチの治療手段のなかで, 金製剂, ク ロロキン製剂の使用は，しばしばリウマチ因子の陰性 化をむたらすといわれているが，35 例中金療法を施 行したものは 12 例であり, そのうち 7 例に RA-Test 陰性化を見ている.

2. 血沈值

全身活動性の指標の1つである血沈值については， 46 年度時にあな损進を示す症例が多数を占めては いるが，その大部分は中等度ないし 軽度の促進であ る.

血沈 1 時間値 $10 \mathrm{~mm}$ 以下の症例は 40 年度時 2 例, 46 年度時 8 例であり, 11 40 $\mathrm{mm}$ の軽ないし中等度 促進例は 40 年度 18 例, 41 年度 20 例であり, $41 \mathrm{~mm}$ 以上の 促進例は 40 年度 15 例に 対し 46 年度は 7 例に 過ぎない。

すなわち 5 年経過後の現在では, アンケート調査に 执いて示めされた朝のてわばり時間の短縮, 疲労発現 時間の延長とともに血沈值む一般の趨勢としては改善 の方向に向っている.

\section{3. その他の検查所見}

慢性関節リウマチにしばしば付随する貧血は 46 年 度の調查時には 35 例中 9 例に 認められたが， 2 例を 除いては軽度であった。

血清蛋白分画では $r$-グロブリンの高值を示す症例 が12例あり, それらの症例の大部分はいまだに比較的 活動性の高い症例であった。

幸運な例を除いて慢性関節リウマチの大部分は長い 経過をたどり, 終始抗炎症剂, 抗リウマチ剂の持続的 な投与を余儀なくされるため，長期投与による副作用 の発現, 特に肝機能障害はもっとあ危惧されるところ であるが，平均 13.5 年の病歷を経過したととになる 46 年度の調查時では, GOT, GPT の上昇を示す症例 はなく, Kunkel, T.T.T の上昇を示す症例が 7 例含 まれている.

しかし，乙れらの7例はいずれも $r$-グロブリンの 上昇があり，肝機能の反映というよりはむしろ $r$-グ ロブリンの量的, 質的変動によるものと思われ, 実際
に以前てれらの膠質反応異常を示していた症例が，そ の後の活動性の低下, $r$-グロブリン值の低下に伴い正 常値に復帰することはしばしば経験するととであり， 今回の調查例中にもそのような症例が含まれている.

しかし今後もなお経過を追い慎重な治療を続けると とが必要であることはあげるまであない。

\section{IV.レ 線 所 見}

レ線変化の経時的な変化を追求することは治療手段 の選択あるいはその反省に重要な示唆を与えるあので ある、その多彩なレ線変化を集計に便宜なように表現 するととは容易ではないが，今回の調查では本来の用 いられ方とは巽なるが Steinbrocker によって規定さ れた 4 段階の Grade を各関節に応用するとととし た.

多数存在する罹患関節のすべてを経時的に撮影する ことは困難であるため, 愁訴の発現することが比較的 少い関節では経時的変化を追求出来た症例は少ない。

たとえば肩関節では僅かに 2 例に過ざず評価すると とは不能である.

时関節については 7 症例， 9 関節の経過を知ると之 が出来たが，46 年度時には 2 関節が I 度にとどまっ ているものの 他の 2 関節は高度の破壊を生じ III 度に 進展している. なお昭和 35 年 41 年度に IV 度に属 していた 1 症例は関節授動術を行なったため 46 年度 時には評価不能となっている.

手関節は橈骨手根関節の読影を主としたが，初診時 I , II 度の軽度の変化を示すに過ぎない関節が 27 関 節，61\%を占めているが， 5 年以上経過後には I 度 は $5.3 \% ，$ II 度は $13.2 \%$ と激減している。

手根間関節はもっとも高頻度に侵され, しかも急速 に破壊され，次いで一塊となって融合する傾向が強 く, 5 年以上経過後には $73.7 \%$ が最終的な IV 度の変 化を生じている.

中手指間関節および指間関節では炎症性破壊過程は 比較的抢だやかであり II 度以下の変化が 半数以上を 占めている.

股関節は愁訴を訴えることが稀な関節ではあるが, 一旦侵されると急激に強く破壊され, しかも protursio acetabuli の傾向をとるととが多いように思われ る.

膝関節は下肢であっともしばしば侵され患者の愁訴 の中心となるが， 5 年以上の経過でも意外化壊過程 
第 1 表 各関節レ線変化の経時的推移

\begin{tabular}{|c|c|c|c|c|c|c|c|c|c|c|}
\hline & \multirow{2}{*}{$\begin{array}{c}\text { No. } \\
\text { of } \\
\text { Case }\end{array}$} & \multirow{2}{*}{$\begin{array}{c}\text { No. } \\
\text { of } \\
\text { Joint }\end{array}$} & \multicolumn{2}{|c|}{$\mathrm{I}$} & \multicolumn{2}{|c|}{ II } & \multicolumn{2}{|c|}{ III } & \multicolumn{2}{|c|}{ IV } \\
\hline & & & $\begin{array}{l}\text { S 35 } \\
\text { S 41 }\end{array}$ & S 46 & $\begin{array}{l}\text { S 35 } \\
\text { S 41 }\end{array}$ & S 46 & $\begin{array}{l}\text { S } 35 \\
\text { S } 41\end{array}$ & S 46 & $\begin{array}{l}\text { S 35 } \\
\text { S 41 }\end{array}$ & S 46 \\
\hline Shoulder & 2 & 2 & 2 & 2 & 0 & 0 & 0 & 0 & 0 & 0 \\
\hline Ellbow & 7 & 9 & $4(44.4)$ & $2(22.2)$ & $0\left(\begin{array}{ll}0 & 0\end{array}\right)$ & $0\left(\begin{array}{ll}0\end{array}\right)$ & $4(44.4)$ & $6(66.7)$ & $1(11.1)$ & $O\left(\begin{array}{ll}0 \\
0\end{array}\right)$ \\
\hline Wrist & 25 & 38 & $10(26.3)$ & $2(5.3)$ & $17(44.7)$ & $5(13.2)$ & $11(28.9)$ & $22(57.9)$ & $0\left(\begin{array}{l}1 \\
0\end{array}\right)$ & $8(21.5)$ \\
\hline lntercarpal & 25 & 38 & $11(28.9)$ & $3(7.9)$ & $14(36.8)$ & $3(7.9)$ & $6(15.8)$ & $4(10.5)$ & $7(18.4)$ & $28(73.7)$ \\
\hline Finger & 20 & 34 & $18(52.9)$ & $5(14.7)$ & $13(38.2)$ & $15(44.1)$ & $3(8.8)$ & $13(38.2)$ & $0\left(\begin{array}{ll}0 & 0\end{array}\right)$ & $1(2.9)$ \\
\hline Hip & 3 & 6 & $4(66.7)$ & $1(16.7)$ & $1(16.7)$ & $1(16.7)$ & $1(16.7)$ & $3(50.0)$ & $O C$ & $0\left(\begin{array}{l}0 \\
0\end{array}\right)$ \\
\hline Knee & 18 & 26 & $11(42.3)$ & $6(23.1) 1$ & $15(57.7)$ & $10(38.5)$ & $0\left(\begin{array}{l}0 \\
0\end{array}\right)$ & $10(38.5)$ & $O\left(\begin{array}{ll}0 \\
0\end{array}\right)$ & OC 0 \\
\hline Ankle & 12 & 20 & $16(80.0)$ & $13(65.0)$ & $3(15.0)$ & $5(25.0)$ & $1(5.0)$ & $2(10.0)$ & $0\left(\begin{array}{ll}0 & 0\end{array}\right)$ & OC 0 \\
\hline lntertarsal & 10 & 20 & $11(55.0)$ & $3(15.0)$ & $2(10.0)$ & $4(20.0)$ & $5(25.0)$ & $9(45.0)$ & $2(10.0)$ & $4(20.0)$ \\
\hline Toe & 9 & 13 & $9(69.2)$ & $6(46.2)$ & $1(7.7)$ & $5(38.5)$ & $3(23.1)$ & $2(15.4)$ & $0\left(\begin{array}{ll}0 & 0\end{array}\right)$ & $0\left(\begin{array}{ll}0 & 0\end{array}\right)$ \\
\hline
\end{tabular}

第 2 表 昭和 46 年度調查時の各関節のレ線変化

（経時的変化を追跡し得なかった症例を含む）

\begin{tabular}{|c|c|c|c|c|c|c|}
\hline & $\begin{array}{c}\text { No. of } \\
\text { Case }\end{array}$ & $\begin{array}{c}\text { No. of } \\
\text { Joint }\end{array}$ & I & II & III & IV \\
\hline $\begin{array}{l}\text { Shoulder } \\
\text { Ellbow } \\
\text { Wrist } \\
\text { lntercarpal } \\
\text { Finger } \\
\text { Hip } \\
\text { Knee } \\
\text { Ankle } \\
\text { Intertarsal } \\
\text { Toe }\end{array}$ & $\begin{array}{r}13 \\
14 \\
30 \\
30 \\
30 \\
6 \\
28 \\
28 \\
28 \\
20\end{array}$ & $\begin{array}{l}24 \\
20 \\
60 \\
60 \\
60 \\
12 \\
52 \\
47 \\
47 \\
39\end{array}$ & $\begin{array}{r}14(58.3) \\
2(10.5) \\
5(8.3) \\
6(10.0) \\
12(20.0) \\
5(41.7) \\
15(28.9) \\
35(74.5) \\
12(25.5) \\
18(46.2)\end{array}$ & $\begin{array}{r}3(12.5) \\
0(0) \\
6(10.0) \\
4(6.7) \\
22(36.7) \\
2(16.7) \\
25(48.1) \\
6(12.8) \\
14(29.8) \\
12(30.8)\end{array}$ & $\begin{array}{r}7(29.2) \\
17(85.0) \\
32(53.3) \\
7(11.7) \\
25(41.7) \\
4(33.3) \\
12(23.1) \\
6(12.8) \\
15(31.9) \\
9(23.0)\end{array}$ & 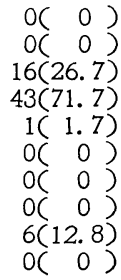 \\
\hline
\end{tabular}

は進展せずほぼ半数は II 度以下の 変化にとどまって いる.

距腿関節は上肢の手関節に相当するにあかかわらず 下肢関節のなかではもっとも多く正常に保たれてい る.

Chopart 関節，足根骨間の関節は手根骨間関節の レ線変化に類似するが強直に至るあのは $20 \%$ 過ぎ ない.

足趾では高度の破壊を呈する症例は䍜患関節数が多 く活動性の強い 2 症例に認めたに過ぎない.

同じ対象症例を以前の経過や現在の愁訴に関係なく 出来るだけ多くの関節についてレ線検索を行なってみ ると，既述した所見と印象を異にするのは，上肢では 肩関節に変化を見出す症例が可成りあり, 現在可動性 も良好で愁訴を欠く症例にも骨頭破壊などの変化を見 出すことである.

下肢ではほぼ類似した数值を示しているが，あっ ともコルチコステロイド注入の機会の多い膝関節で Charcot 関節様の変化を呈する症例が 1 例見出され
た. しかし, この症例では高度の関節液眝留をくり返 えすととああって強い動摇性を示しており，その変化 がコルチコステロイド注入のみに基因させて良いかど うかはなお疑問である.

なお，さらに興味があることは可成り強い炎症性破 壊が生じていたにあかかわらず，長い経過の後にはそ れらが次第に修復され, 炎症性変化に代って変性変化 が進展していると解釈される所見を時に見出すことで ある。

したがって長く経過した慢性関節リウマチでは変性 変化が実際の愁訴に強く関与する場合があるととを考 慮に入れておかねばならないであろう.

\section{V. まと め}

慢性関節リウマチ 長期観察例，35 例の 病態につい て主としてその経時的変動を検討した.

昭和 41 年度の調査時に 平均罹病年数 8.5 年であっ たとれらの症例の全身活動性は 5 年以上経過後には低 下の傾向にある症例が増加し, リウマチ因子の検出率 


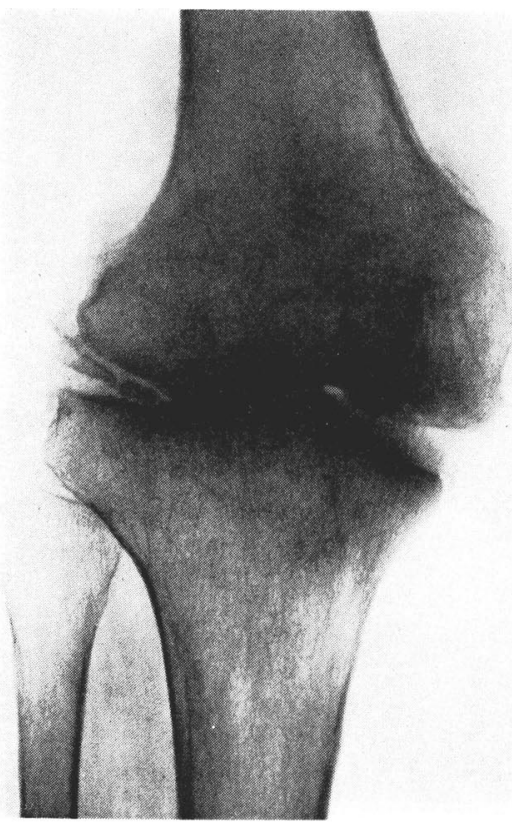

第1図50才，男性，左膝関節の Charcot 関節様変化

屯減少の傾向にある.

レ線所見では各関節部位によってその様態は異なっ ており, 5 年経過の間にその変化が強く進展する関節 屯あれば，破壊過程は比較的僅少にとどまるあのああ る.

このように各症例の炎症活動性の強弱のみでなく， 関節部位によって破壊過程の進展度が異なるのは各関 節の構造上の差異, たとえば可動範囲, 関節腔の大小 , 滑液膜の分布, 血管供給の問題, 荷重負担の有無な ど種々の因子によるものであろうし，今後そのような 面からの検討がなされればならないが，他方では手術 侵襲, 特に滑液膜切除術や，コルチコステロイド関節 内注入などの治療手段が，ある関節では容易で豊富で あり, ある関節では困難でそしいなどの要素も関与し ているあのと思われる.

\section{文献}

1) Duthie, J. J., Brown, D. E., et al: Ann rheum Dis. 23, 193, 1964.

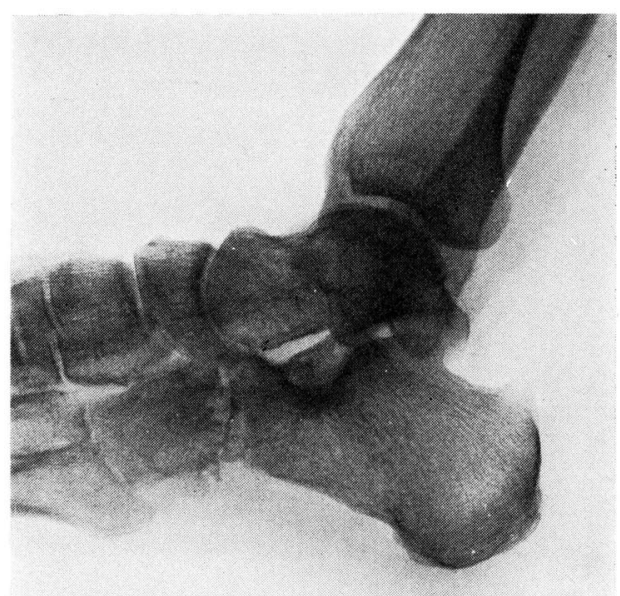

第2 図a 37才，女性の足部レ線像（昭和40年） 踵立方関節に炎症性骨破壊像が認めら れる

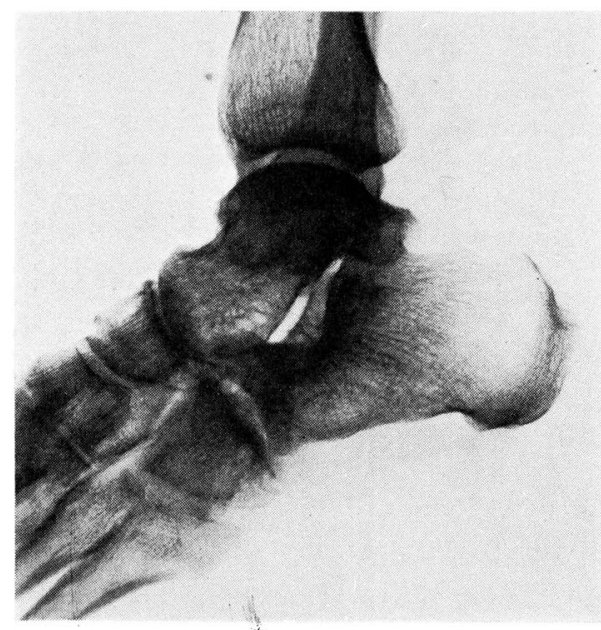

第 2 図b 6 年後の足部レ線像，踵立方関節の炎 症性破壊は消失し，軟骨下骨質の硬化 像などの変性変化が認められる

2) Ragan, C.: J. Amer. Med. Assc. 141, 124, 1949.

3）塚本行男 - 有富 寛 - 山本 真：臨床整形外科 投稿中

4）山本 真・塚本行男・他：リウマチ 7,267 , 1967. 